\section{E-LOGOS}

ELECTRONIC JOURNAL FOR PHILOSOPHY ISSN 1211-0442

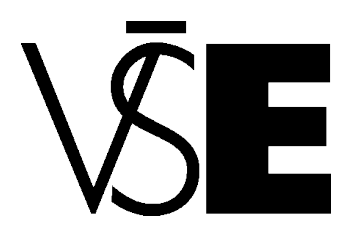

University of Economics

Prague

\title{
Brněnská ekonomická škola a mezní
}

\section{užitek}

Tomáš Vaverka

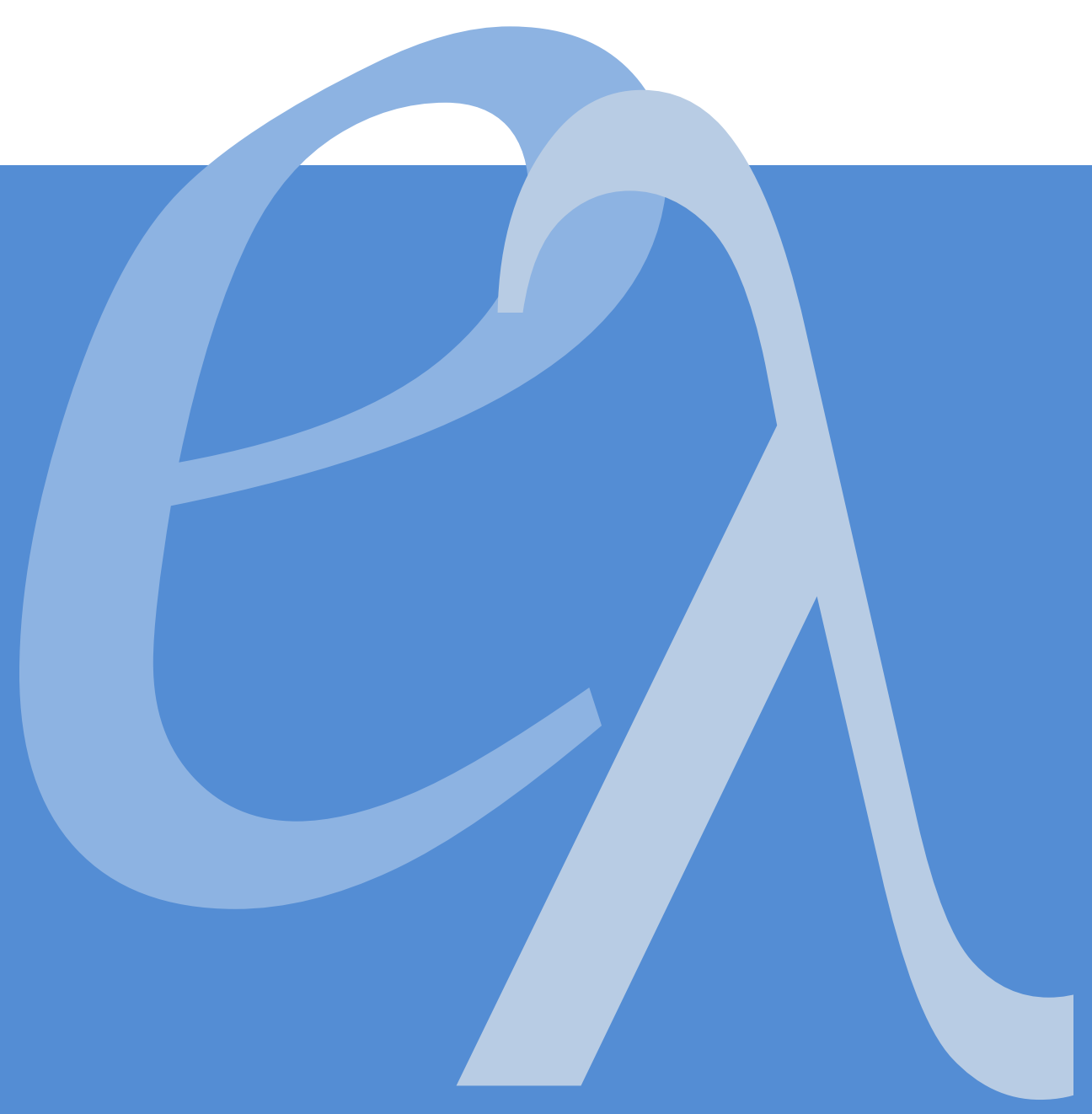




\begin{abstract}
The discussion over the character of economics as an exact science is still vivid. During the $20^{\text {th }}$ century the attempts to establish the solid foundations for the exact economics are to be found by the authors of the Austrian school of economics. The same thought emerges by the Brno school as well where there is an explicit claim on epistemological purification of economics.

This article describes the common features of both above mentioned approaches which can be seen particularly in deriving the law of diminishing marginal utility by purely formal methods. Furthermore, on the grounds of this analysis, there are uncovered the general conditions of the possibility to develop economics as an exact science.
\end{abstract}

\title{
Abstrakt
}

Diskuse nad charakterem ekonomie jako exaktní vědy je stále živá. V průběhu 20. století bývají pokusy o exaktní založení ekonomie spojovány s autory Rakouské ekonomické školy. Stejná myšlenka se objevuje také u autorů Brněnské ekonomické školy, kde vystupuje požadavek na noetickou očistu ekonomie.

Tento př́ispěvek popisuje společné rysy obou těchto přístupů, které je možné spatřovat v odvození zákona klesajícího mezního užitku čistě formálními metodami. Na základě této analýzy dále odhaluje obecné podmínky možnosti traktování ekonomie jako exaktní vědy.

\section{Key words:}

Apriorism, Teleology, Praxeology, Impozicionism

\section{Klíčová slova:}

Apriorismus, Teleologie, Praxeologie, Impozicionismus 


\section{Úvod 1}

Představa ekonomie jako empirické vědy o společnosti je mezi ekonomy značně rozšiřrená. Jen o něco méně uznávaná je představa o výpovědní schopnosti ekonomie, která je určena schopností ekonomických modelů s empirickými předpoklady predikovat výsledky interakcí reálných bytostí. Přestože již D. Hume dostatečně jasně ukázal nemožnost s jistotou rozhodnout o tom, co bude, na základě toho, co bylo (tzn. formulovat zákon na základě neúplné indukce), nezdá se, že by se ekonomové př́liš poučili.

Každý, kdo ekonomii prohlašuje za empirickou vědu, by si měl uvědomit, že pro to, aby mohl být směrem ke skutečnosti vznesen nějaký dotaz související s ekonomií, musí být nejprve (jako ekonomický) formulován. V jiných případech musí být výsledky empirických ekonomických zkoumání nějak interpretovány, aby mohly být vůbec řazeny mezi poznatky ekonomické. Takový výstup, at' již formulace dotazu a nebo interpretace výsledků, předpokládá konstrukci nějakého abstraktního ekonomického modelu. Ostatně proto, že každá snaha o uchopení hospodářského jednání předpokládá konstrukci abstraktního modelu, není základem ekonomie v podstatě nic jiného než soubor různých modelů $v$ myslích ekonomů, kteří tyto modely využívají.

Je tedy ekonomie skutečně věda empirická, nebo je spíše vědou logickou? Může být dokonce vědou exaktní? Tato studie vychází z výše zmíněného předpokladu, že ekonomie nemůže být čistě empirickou vědou. $O$ př́itomnosti logické metody v rámci ekonomie nemůže být sporu, nebot' je nejsilnější zbraní ekonoma v souboji s nejistotou jeho vlastních závěrů. Nezvratná jistota v rámci intelektu doslova nutí vědce při analýze využívat logické nástroje. At' již při formulaci předpokladů, vymezení přípustných situací nebo při interpretaci výsledků empirických zkoumání. Pokud se podíváme na převládající trendy ve vývoji ekonomie, resp. v uplatňování ekonomických modelů, je možné ve všech spatřovat zapojení logiky.

Přestože je snahou tohoto textu ukázat, že je smysluplné požadovat oddělení (souboru, systému či struktury) čistě logických a tedy exaktních ekonomických poznatků, není jeho úmyslem polemizovat stím, že k formulování, či využití takových poznatků (ekonomického nástroje) je nezbytné empirické předpoklady přiřadit. Na druhou stranu tím, že jsou čistě logické poznatky pro intelekt zcela jisté, zůstává vhodnost jejich aplikace zcela závislá na přijatých empirických předpokladech.

1 Tato studie vznikla v rámci grantového projektu „Evoluční modelování“ financovaného interní grantovou agenturou VŠE: IG506020 


\section{Ekonomie a logika}

Proč není ekonomie považována za exaktní vědu? Dnes nejrozšǐřenější neoklasická ekonomie může být charakterizována důsledným využitím logické metody při získávání výsledků svého zkoumání. Tato ekonomie tzv. „hlavního proudu" využivá různé empirické hypotézy $\mathrm{k}$ tomu, aby z nich za pomoci logické metody vyabstrahovala výsledky, které jsou pro intelekt logicky (apodikticky) nutné, ovšem pouze a jen vzhledem k těmto hypotézám. Jinými slovy: Každému, kdo by chtěl následně za použití stejných výchozích předpokladů dojít k nějakým výsledkům, nemohly by se tyto od těch původních vůbec lišit. Komplikace tohoto přistupu tedy nespočívá v metodě získávání vědeckých soudů (výsledků), nebot' je vždy možné postup znovu a znovu opakovat se stejnými výsledky a př́padný logický omyl odhalit (tak jako při zkoušení studenta z neoklasiky), ale v základu pro využití takové metody. Tedy prrímo $\mathrm{v}$ samotných empirických předpokladech abstraktního ekonomického modelu a tedy v možnostech aplikace takového modelu na skutečnost.

Co můžeme říci $\mathrm{k}$ využití logické metody v rámci výrazně se prosazujícího př́stupu ke zkoumání ekonomických problémů - tzv. teorii her? Metoda tohoto př́stupu rovněž požívá apodiktické jistoty využitím logické metody. Prostor pro využití logické metody se však efektivně zužuje zaváděním podmínek (předpokladů modelu, tak jako tomu bylo u neoklasiky) tak, aby výsledná odpověd' specificky odpovídala potřebám ekonoma. Jednotliví agenti tak pokaždé v rámci stejných podmínek zaznamenají stejný a nutný výsledek svých akcí. Tak jako bylo u neoklasické ekonomie zavedení předpokladů (dokonalá konkurence, stálé preference atd.) úskalím, díky němuž výsledky této vědecké práce ztrácí svou apodiktickou jistotu vzhledem ke skutečnosti, jsou úplně stejným ohrožením této jistoty $\mathrm{v}$ rámci teorie her vstupní podmínky pro zúčastněné agenty. Velice úzká specifikace možných akcí jednotlivých agentů $\mathrm{v}$ některých případech přináší do teorie her značnou pochybnost, která se zdá být téměř prrímo úměrná realističnosti, př́íp. úplnosti přijímaných podmínek.

Může tedy ekonomie být exaktní vědou? Základním problémem podmínek, které jsou odpovědné za ztrátu apodiktické jistoty u obou výše zmíněných př́padů je jejich empirický původ. Tím se dostáváme ke druhé, pro ekonomii však důležité, otázce. Na jakých předpokladech ekonomie, která musí využívat logickou metodu, stojí? Na logických a nebo empirických? Jsou předpoklady ekonomického modelu empirické a nebo logické? Toto je metodologická otázka, která se stále vrací s tím, jak velkou část mezi ekonomy tvoří ti, pro které je ekonomie postavená na empirických (mnohdy psychologických) základech filosoficky nepřijatelná. Jaké jsou tedy podmínky možnosti traktování ekonomie jako exaktní vědy? Je možné vystavět model ekonomického myšlení pouze na základě zákonů logiky? Protože se $\mathrm{v}$ dějinách ekonomického myšlení setkáváme s nemnohými pokusy o založení ekonomie jako 
exaktní vědy o společnosti, budou v následující části reflektovány některé přístupy, z nichž se ukáže patrné, že zdůvodněním zákona o nutném klesajícím relativním čistém subjektivním výnosu ${ }^{2}$ mezním čistě logickými metodami je možné takového cíle dosáhnout.

\section{Praxeologie a ekonomie}

Ve 20. století bývá mezi kritiky zastánců empirické ekonomie řazena především (neo)rakouská ekonomická škola, u které jako fundament ekonomie (poněkud nešt'astně nepřímo) vystupuje logický zákon klesajícího mezního užitku. ${ }^{3} \mathrm{~K}$ logické, pro intelekt apodikticky jisté, formulaci zákona klesajícího relativního mezního užitku a zákona o tendenci $\mathrm{k}$ vyrovnávání těchto užitků prostřednictvím hospodářské činnosti - volby, dochází rovněž Brněnská ekonomická škola prací K. Engliše a J. Loevensteina.

Nejznámějším představitelem požadavku po čistě logické ekonomii je L. Mises. Ve své čistě formální a obecné praxeologii uchopuje logiku účelové činnosti tak, že všechna tvrzení dedukuje ze základního axiomu lidského jednání - man acts - člověk účelově jedná. Ve své snaze se Mises značně inspiruje Kantovým př́istupem k poznávání předpokladů možnosti empirického poznání vůbec. Centrem Misesovy pozornosti se stává kategorie jednání, která je ve své nutné podobě obsažena v logické struktuře lidské mysli. Deduktivní postup využívající logickou metodu (zákony formální logiky) rovněž v rámci transcendentálního schématu neopouští tuto nutnou strukturu lidské mysli. ${ }^{4}$ Misesova praxeologie spočívá v tom, že využivá tohoto apriorního nástroje ke klasifikaci reálného světa tak, že do řetězu logických dedukcí vkládá další empirické předpoklady, které se v reálném světě vyskytují.

\footnotetext{
${ }^{2}$ Toto pojmové určení je výsledkem Loevensteinovy analýzy teleologického myšlenkového řádu. Čistý subjektivní výnos mezní není nic jiného než mezní užitek vystupující u ostatních autorů (Rakouská škola, Engliš) V tomto textu budou oba termíny vystupovat jako identické vždy podle toho, kdo s nimi operuje. Pojem mezního užitku je $\mathrm{v}$ textu užíván rovněž velmi podobně jako v současné mikroekonomii. Jediným, i když nikoli nepřekročitelným, rozdílem je čistě formální (logický či pojmový) původ.

${ }^{3}$ Za základní kámen ekonomické analýzy je mezní užitek považován od marginalistické revoluce na konci 19.století, znovuobjeven a doložen byl však již H. H. Gossenem v polovině 19. století (Gossenovy zákony). Kategorie účelového jednání je v Misesově praxeologii základním axiomem a zákon mezního užitku je v této kategorii obsažen: „Není ničím jiným než převráceným tvrzením, že to, co přináší větší uspokojení, je upřednostňováno před tím, co přináší uspokojení menší. Pokud se dostupná zásoba zvýší z n-1 jednotek na $\mathrm{n}$ jednotek může být tento přírůstek použit pouze na odstranění potřeby, která je méně naléhavá či nepříjemná než nejméně naléhavá či nepřijemná potřeba ze všech, které mohly být odstraněny s použitím zásoby n-1." (Mises 2006, str. 112)

4 „V̌̌echny praxeologické kategorie jsou věčné a neměnné, protože jsou jedinečně určeny logickou strukturou lidské mysli a přirozenými podmínkami lidské existence....Takové jednání, které se kategoriálně liší od jednání vymezeného těmito kategoriemi, není pro člověka ani možné, ani myslitelné.“ (Mises 2006, str.179)
} 
Takto získané poznání je vždy platné, nepodléhá a nemůže podléhat žádné falsifikaci či verifikaci, pouze však v případě výskytu daných empirických předpokladů ve skutečném světě má toto poznání praktický význam.

Jak se k Misesově praxeologii staví jeho pokračovatelé v rámci rakouské tradice? Termín praxeologie slouží jako pojmenování specifické metody, která je autory rakouské školy využívána. Tato metoda má svůj původ v praxeologii Misesově ovšem v některých ohledech se odlišuje. Zejména pokud jde o epistemologický původ základního axiomu jednání.

Mnozí Misesovi stoupenci z řad rakouské tradice (např. Rothbard) se pokoušejí založit základní axiom (a některé pomocné axiomy) empiricky, případně fenomenologicky (C. Menger). ${ }^{5}$ Tyto poznatky jsou po svém vyřčení považovány za apriorně platné (self-evident). Tento apriorní charakter však pochází z esenciálního určení jednotlivých, mysli přístupných, kategorií reality a nikoli kategorií lidské mysli. ${ }^{6}$ Pro Rothbarda je kategorie lidského účelového jednání potvrzována jako apriorní naší vnitřní a vnější zkušeností. To, že lidé jednají účelově, je za prvé zcela patrné a za druhé není ani možné o tomto popření uvažovat, nebot' již samo toto uvažování by bylo účelovým jednáním (sledující jako cíl popření axiomu jednání).

Nehledě na spor o původ fundamentálního axiomu je metoda získávání apriorních poznatků v rakouské tradici shodná. Pokud původ axiomu jednání ponecháme stranou, nebot' pro zdůvodnění mezního užitku a logické tendence $\mathrm{k}$ jeho klesání není nutné původ tohoto axiomu vyšetřovat, jak se ukáže při zkoumání téhož $\mathrm{v}$ rámci Brněnské ekonomické školy, nezbývá než uzavřít tím, že $\mathrm{v}$ postupu $\mathrm{k}$ získávání apriorně platných poznatků o realitě již celá rakouská tradice využívá stejnou čistě logickou (deduktivní) metodu. Zákon klesajícího mezního užitku je tedy rovněž např. v Rothbardově pojetí logickou součástí empirické kategorie účelového lidského jednání. ${ }^{7}$ H. H. Hoppe na základě čistě logického zákona o klesajícím mezním užitku ${ }^{8}$ dokládá např. dedukci zákona klesajících výnosů z výrobních

\footnotetext{
${ }^{5}$ Menger při určení ekonomických kategorií nevychází z Kantova idealismu jako později jeho žák von Mises, nýbrž chápe poznání apriorních podstat jako nutných a podstatných určení vněǰśi reality, která existují nezávisle na našem vědomí a jsou zároveň ve svých podstatných určeních inteligibilní, tj. př́stupná našemu poznání. (Pavlík 2004)

${ }_{6}$ Odlišení impozicionismu a reflekcionismu v rámci metodologického apriorismu viz dále (B. Smith 2008)

7 „Důležitou otázkou je vztah mezi získávanou či obětovanou jednotkou a množstvím (nabídky) zásoby, která je již jednajícímu k dispozici. Není-li dostupná žádná jednotka statku (at’ se jedná o jakýkoli statek), bude první jednotka uspokojovat nejnaléhavější potřebu, kterou může takový statek uspokojit. Je-li k této nabídce přidána druhá jednotka, bude tato jednotka naplňovat nejnaléhavější ze zbývajících potřeb, které však budou méně naléhavé než ty uspokojované jednotkou první." (Rothbard 2005, str.15) 8 H. H. Hoppe definuje klesající mezní užitek následovně: „Kdykoli vzroste nabídka statku o dodatečnou jednotku, pak za předpokladu, že je schopnost každé jednotky uspokojit danou službu považována člověkem za stejnou, hodnota přisouzená této jednotce musí klesnout. Tato dodatečná jednotka totiž může být použita jen $\mathrm{k}$ uspokojení cíle, který je považován za méně hodnotný než
} 
faktorů, jenž se objevuje již u Misese, či zákona komparativních výhod. Přestože spor v rámci rakouské školy ohledně původu Misesova základního axiomu jednání pravděpodobně hned tak neutichne, pro založení exaktní ekonomie není jeho vyřešení nezbytné. To, co autory rakouské tradice navzájem spojuje, je pojí rovněž s učením Brněnské ekonomické školy. Jedná se o logické zdůvodnění zákona o klesajícím mezním užitku, které následně může být základem pro dedukci dalších exaktních ekonomických zákonů. Nikoli však apodiktických zákonů skutečného jednání jak se domnívá Mises, ale pouze nutných zákonů teleologického (účelového), příp. hospodářského myšlení.

\section{Teleologie a ekonomie}

Podstatou ekonomie postavené na logických základech v rámci Brněnské ekonomické školy je způsob myšlení. Pro Engliše to znamená způsob usouvztažňování myšlenkových obsahů v rámci formálních myšlenkových řádů. Engliš rozeznává tři přirozené myšlenkové řády, které odvozuje z přirozeného jazyka. V ontologickém myšlenkovém řádu jsou myšlenkové obsahy pořádány podle zákona kauzality a jsou představovány jako existující, je to náš deterministický fenomenální svět (Kant). V tomto myšlenkovém řádu je člověk pouze součástí determinovaného světa, svoboda není nahlédnutelná, a pro vysvětlení jednání člověka je nutno pouze najít a dešifrovat vjemy, které na něho působily, tedy motiv jeho jednání. ${ }^{9}$

Svoboda je uchopitelná pouze prostřednictvím teleologického myšlenkového řádu. Svoboda se projevuje tím, že člověk jedná - volí. V teleologickém myšlenkovém řádu, kde se myšlenkové obsahy usouvztažňují účelovým (finálním) vztahem, je možné uchopit nejen svobodu, ale také další teleologické pojmy (účel, prostředek, užitek, výnos, náklad) společně s jejich apodiktickými vztahy. Tyto vztahy pojmů jsou poté základem apodiktické jistoty našeho intelektu při prací $\mathrm{s}$ těmito vztahy $\mathrm{v}$ rámci dotyčného myšlenkového řádu (systému nutných vztahů). Povinnost, at' již zákonná či mravní, je uchopitelná pouze v normologickém myšlenkovém řádu. Stejně tak správnost předpokládá nějakou normu. V Englišově pojetí je také noetika - formální věda o přirozených myšlenkových řádech a možnostech jejich použití takovou normou správného myšlení. Každý soud o empirické realitě může být podle Engliše nejen klamem, ale také omylem. Nejenom, že nemusí být empiricky pravdivý, především nemusí být formálně správný. ${ }^{10}$

nejméně hodnocený cíl uspokojený poslední jednotkou statku před získáním dodatečné jednotky." (Hoppe 1995, str. 11)

9 Přestože Engliš v mnohém Schopenhauera kritizuje, nepochybně se u něho inspiroval. Englišův žák Jan Loevenstein již při svém přepracování teleologie ze Schopenhauera explicitně vychází. (viz. dále) 10 Oblíbeným Englišovým př́kladem nesprávného (takového, jež porušuje formálně-logickou normu správného myšlení) soudu je soud: Otec neměl dětí. Nesprávnost myšlení zakládá nejen nesprávné 
Přestože je pochopitelně možné vykládat hospodářskou činnost kauzálním myšlenkovým řádem, Engliš to považuje za myslitelné pouze při hromadném pozorování osob. Tím, že pro ekonomii stanovil jako vhodný zpưsob pořádání myšlenkových obsahů řád teleologický, se Engliš nepřímo přihlásil k metodologickému individualismu, který důsledně razí rakouská škola. Přestože svým rozdělením teleologie mezi dva myslitelné nejvyšší účely ${ }^{11}$ zakládá prostor pro teleologickou teorii objektivistickou a potažmo systém solidaristický, jednoznačně se vyslovuje pro vhodnost posuzování lidského jednání z hlediska osobní spokojenosti podle apriorních zákonů teleologického myšlení a rozvíjí teleologickou teorii subjektivistickou, jenž se ve svých logických požadavcích vůbec neodlišuje od Misesovy praxeologie. ${ }^{12}$

Englišův žák a pokračovatel Jan Loevenstein vypracoval teleologii na základě rozporů $\mathrm{v}$ teleologii Englišově. Loevensteinův nesouhlas s označením finality jako racionality, kterou je teleologický myšlenkový řád určený, jej přivede až ke studiu základi̊ Englišovy noetiky u Kanta a Schopenhauera.

Jeho vzorem se stává rozdělení poznání v Schopenhauerově práci $O$ čtverém kořeni věty o dostatečném dưvodu. Schopenhauer se pokouší rozdělit apriorní vztahy

použití pojmů $\mathrm{v}$ rámci myšlenkového řádu, ale také použití (promíchání) pojmů z různých myšlenkových řádů. Pokud však pojmy dotyčného myšlenkového řádu použijeme správně, aplikace se již stává otázkou vhodnosti. Jako vhodné se ukázalo v přírodních (materiálních) vědách použití kauzálního myšlenkového řádu, ovšem ve vědách společenských nepřináší podle Engliše (a dalších) pro intelekt tak uspokojivé výsledky jako řád teleologický.

${ }^{11}$ Nejvyšší účel v Englišově terminologii je tím účelem, který je dále neredukovatelný na prostředek $\mathrm{k}$ dalšímu účelu. Protože hospodářské jednání je u Engliše v podstatě neustálým teleologickým hodnocením nemusí subjekt tohoto hodnocení při volbě mezi užitím různých prostředků vždy vystupovat až $k$ tomuto nejvyššímu účelu, ale pouze $k$ tomu účelu, který je oběma nižším (porovnávaným) účelům nadřazen. Jako nejvyšší účely Engliš navrhuje použití osobní spokojenosti pro sféru subjektivistickou a ideál (člověka, národa či lidstva) pro sféru objektivistickou. Základním rozdílem v těchto sférách je sdělitelnost hodnocení subjektu. Onen objektivní ideál a hodnocení vzhledem k němu (teleologické hodnocení) je sdělitelné, naproti tomu hodnocení subjektu (patrně všech psychofyzických lidí) vzhledem k subjektivnímu nejvyššímu účelu osobní spokojenosti je mezi subjekty nesdělitelné, pouze každý jednotlivý subjekt má možnost svá alternativní jednání vzhledem k subjektivnímu nejvyššímu účelu porovnat. Zároveň je podle Engliše potrestán "brentanovskou“ sankcí nesprávnosti, uvědomí-li si, že se nerozhodnul podle zákona o vyrovnání mezních užitků relativních a mezních nákladů relativních (V Englišově terminologii poněkud nešt́astně (Loevenstein) nazváno myšlením pod maximálním účelem)

12 Není náhodou, že Mises se ve své Human Action o Englišově odkazu zmiňuje. Doslova nezaslouženě stručná zmínka však naznačuje polemiku, kdy Mises prohlašuje, že k uchopení reality jsou člověku k disposici pouze principy kauzality a teleologie. (Mises 2006, str. 33) Englišův třetí přirozený myšlenkový řád byl patrně odmítnut. Na druhou stranu je odlišení teleologického a normologického řádu u Engliše pro F. A. Hayeka důvodem smíŕlivějších slov na adresu jeho teorie myšlenkových řádů (Hayek 1995). Rozlišení teleologie a normologie v oblasti hodnot nezbytných pro vysvětlení ekonomického jednání zmiňuje rovněž A. P. Becker (1948), podle něǰž je pro ekonomii zásadní nezaměňovat hodnotové soudy s nezbytným zkoumáním hodnot (nikoliv pouze ekonomických). 
mezi všemi myslitelnými představami do čtyř skupin věty o dostatečném důvodu. ${ }^{13}$ Loevenstein ve své noetice $z$ tohoto rozdělení vychází, přičemž jej následovně modifikuje:

Kořeny věty o dostatečném důvodu u něho vystupují pouze tři ratio sufficiens fiendi, iudicanti a essendi tedy věta o dostatečném důvodu dění, souzení a bytí. Čtvrtá tř́ida představ u Loevensteina pochopitelně zcela chybí a Schopenhauerův zákon motivace, jenž za př́íčinu jednání označuje (kauzálně) motiv, je kritizován rovněž Englišem jako transposice kauzality do teleologie.

Hlavní pozornost je ovšem upřena k druhé třídě (abstraktních) představ. Podle Schopenhauera může být poznatek zdůvodněn čtyřmi zpơsoby: Formálně, materiálně, transcendentálně a metalogicky. Toto rozdělení je podle Loevensteina jistě možné a př́inosné, ovšem zdůrazňuje, že je možné každý poznatek z této třídy představ považovat za zdůvodněný logicky. Pokud zdůvodňuji soud formálně (jiným soudem), mohu tak činit do nekonečna. Teprve zdůvodnění metalogické (formální logika) zdo̊vodňuje daný poznatek. Stejně tak zdůvodnění materiální (smysly) není možné označit za obecné, pokud není zdůvodněno transcendentálně (apriorní formou času, prostoru a kauzality).

Loevenstein tedy tvrdí, že poznatky, jejichž spojitost je nám ve vědomí takto dána logickou racionalitou, pocházejí pouze ze soudů (spojení pojmů), které mohou být pouze myšleny a nikoli získány názorem. V třídě abstraktních představ tak vystupuje věta o dostatečném důvodu souzení (nikoli poznání), která své zdůvodnění čerpá vždy z logické racionality. Apriorismus v rámci teleologického myšlenkového řádu je $u$ Loevensteina možné vyjádřit jako strukturu vztahů teleologických pojmů, jejíž nutnost spočívá v logickém důvodu. ${ }^{14}$

13 „Naše poznávací vědomí, vystupující jako vnější a vnitřní smyslovost (receptivita), rozvažování a rozum, se rozpadá na subjekt a objekt a neobsahuje kromě toho nic. Být objektem pro subjekt a být naší představou je totéž. Všechny naše představy jsou objekty subjektu a všechny objekty subjektu jsou naše představy. Nyní se však ukazuje, že všechny naše představy navzájem jsou v zákonité a podle formy apriorně určitelné vazbě, díky níž se nic pro sebe trvalého a nezávislého a také nic jednotlivého a odtrženého nemůže pro nás stát objektem. Toto spojení je tím, co ve své obecnosti vyjadřuje věta o dostatečném důvodu." (Schopenhauer 2007, str.55) U tř́́dy názorných, úplných a empirických představ vystupuje věta o dostatečném důvodu ve formě kauzality. U třídy abstraktních představ (pojmů, resp. soudů) jako věta o dostatečném důvodu poznání, která může mít své zdůvodnění formální (jiným soudem), materiální (smysly), transcendentální (čas, prostor, kauzalita) nebo metalogické (zákony myšlení - formální logika). Třetí tř́ídu objektů tvoří apriorní nazírání forem čisté smyslovosti (čas a prostor) bez př́tomnosti hmoty (tedy aritmetika a geometrie), kde vystupuje věta o dostatečném důvodu bytí a konečně čtvrtou, pro Schopenhauera zcela specifickou, tř́́du představuje tzv. bezprostř̌ední objekt vnitřního smyslu neboli subjekt chtění (vůle), kde vystupuje věta o dostatečném důvodu jednání, stručně zákon motivace.

14 Pro Loevensteina to znamená, že v této struktuře logická racionalita (důvod) převládá. Dostatečný důvod dění či bytí figuruje $\mathrm{v}$ rámci teleologického myšlení jako (často nepodstatný) předpoklad. „Naproti tomu v teleologii je nám kausální poznatek pouze jednou z premis, jak uvidíme, a to premisou, jejíž pravdivost zpravidla ani neověřujeme. Kauzální poznatek jest zde pomůckou. Za to logický soud a úsudek, řízený logickou racionalitou, zde funguje jako čistě poznávací instrument (arci jen po formální 
Loevenstein stejně jako Engliš tyto apriorní vztahy odhaluje u pojmů teleologického myšlení. V rámci teleologického myšlení rozděluje fázi technickou (např. pojmy účel, prostředek, užitek, škoda, potřeba, upotřebitelnost) a specifickou fázi hospodářskou (náklad, výnos, hodnota, hospodaření). ${ }^{15} \mathrm{~V}$ technické fázi je účel myšlen jako izolovaný (resp. jediný a nekomplikovaný). O hospodářskou fázi jde v případě, že splnění základního účelu předpokládá kolizi mezi účely zprostředkujícími a tím pádem nutnost volby. Specificky hospodářské pojmy mají svůj význam pouze $\mathrm{v}$ rámci hospodářského myšlení. Z pohledu izolovaného účelu nejsou náklad ani hodnota uchopitelné. ${ }^{16}$

V rámci hospodářského myšlení se Jan Loevenstein dopracuje až $\mathrm{k}$ formulaci zákona (pojmu) maximálního čistého výnosu17, kterým vysvětluje logický sylogismus při rozhodování $\mathrm{k}$ jednání. Tento postulát označuje nejvyšším a základním principem, ze kterého je možné odvodit zákon o klesajícím relativním čistém subjektivním výnosu (užitku) mezním (III. Gossenův zákon) i zákon o tendenci $\mathrm{k}$ vyrovnávání těchto relativní mezních subjektivních výnosů (II.Gossenův zákon $)^{18}$ prostřednictvím hospodářské volby - tedy čistě logického rozhodnutí $\mathrm{k}$ jednání. ${ }^{19}$

stránce), nikoliv tedy jako tomu je začasté $\mathrm{v}$ př́rodních vědách, jako instrument enunciační."(Loevenstein 1934, str.38)

15 Rozdělení teleologického myšlení mezi odlišné fáze společně s pojmovými vztahy je možné $\mathrm{s}$ úspěchem aplikovat na rekonstrukci základních pojmů užívaných v rakouské tradici. Do této kategorie spadá rovněž pojmové spojení užitku a škody se spojením nákladu a výnosu v jejich vzájemné odlišnosti $\mathrm{v}$ rámci různých fází teleologického myšlení. Důsledkem je pak nemožnost odhalit nutný vztah např. pojmové dvojice užitek - náklad, která je nedůsledně využívána Misesem a může být označena za pramen různých druhů sporů, nebot' něco může být velmi užitečné, přestože to nemusí přinést $\mathrm{v}$ důsledku nutné volby subjektu subjektivní výnos (užitek).

${ }^{16} \mathrm{~V}$ tomto smyslu Loevenstein technickou fázi účelového myšlení ilustruje takto „Můžeme po té stránce říci $v$ tropickém smyslu, že caesarové a děti se dívají na svět pouze technicky (neznají nákladu, znají jen své: já chci).“ (Loevenstein 1929, str.29)

${ }^{17}$ Pojem maximum čistého výnosu je velmi zjednodušeně obsažen v hospodářské úvaze jako nejvyšší saldo mezi výnosem a nákladem vzhledem ke kritickému postulátu (tedy účelu dané fáze) "tento postulát (maximálního čistého výnosu) jest jakýmsi společným uzlem všech jednotlivých dosud v teorii národohospodářské odvozených zákonů, což svědčí o tom, že jest hospodářským postulátem základním." (Loevenstein 1934, str.343)

18 Tradiční formulace Gossenova zákona klesajícího mezního užitku - „U kvalitativně stejného prostředku uspokojování se s přidáváním dalších jednotek tohoto prostředku $\mathrm{k}$ dané zásobě neustále zmenšuje kvalita uspokojení poskytovaná každou nově přidanou jednotkou.." variant tzv. II Gossenova zákona je více. Maximalizaci užitku při sestavování rozpočtu charakterizuje následovně: „...Osoba dosahuje maxima svého užitku tehdy, když nutně omezené množství peněz, které má $\mathrm{k}$ dispozici, rozděluje mezi různé statky tak, aby z posledního atomu vydaného př̌i koupi každého statku dosáhla stejné kvantity uspokojení" cit. z (Pavlík 2004, str.624)

19 Apriorní charakter nejvyššího hospodářského zákona může u Loevensteina ilustrovat následující prohlášení o hospodaření, které je pojmově označováno jako aplikace zákona maximálního čistého výnosu každým subjektem, který volí „srovnává tedy výnos s nákladem a snaží se po dosažení jejich maximálního salda. Všechno ostatní, co jest jako snažení hospodařícímu člověku připisováno ve formě různých zákonů, jest bud’ důsledkem uvedené zásady, nebo jest nesprávné.“ (Loevenstein 1934, str.340) 


\section{Teleologie a praxeologie}

Co mají tyto př́istupy společné? Metodologická shoda panuje právě v otázce teleologie. Pro Misese je to jeden ze dvou možných principo̊ uchopení reality, což se od Englišova pojetí liší jen $\mathrm{v}$ tom, že Mises ignoruje normologický princip. U Loevensteina se také vyskytují tři výše popsané Englišovy myšlenkové řády s tím, že tzv. racionality myšlení jsou pouze dvě. Tím, že Loevenstein označil pro normologický a teleologický myšlenkový řád společnou racionalitu (logický důvod), vyjasnil největší metodologický nesoulad mezi teleologií Brněnské ekonomické školy a praxeologií Misesovou. Loevenstein dále teleologický způsob myšlení dělí mezi myšlení technické a hospodářské. Hospodářské myšlení je takové, které předpokládá volbu a tím se logicky shoduje se základním praxeologickým požadavkem Misesovým, pro kterého je každé jednání volbou (směnou) mezi alternativami. ${ }^{20}$

Důležité je však to, že snaha o uchopení reality probíhá jiným způsobem než u moderní ekonomie. Teleologie - logika účelové činnosti postupuje pouze za pomoci logiky. V podání Brněnské ekonomické školy hledá nutné vztahy mezi jednotlivými pojmy, které jsou pro daný myšlenkový řád specifické (prostřednictvím jiných myšlenkových řádů nejsou uchopitelné). Engliš tímto způsobem založí zákon klesajícího mezního užitku relativního tak, že větší očekávaný užitek vždy logicky (nikoli vždy empiricky v čase) předchází užitku menšímu. Loevenstein dokonce zákon o klesajícím subjektivním výnosu mezním vysvětluje jako důsledek zákona o maximalizaci čistého výnosu subjektem v rámci hospodářské fáze teleologického myšlení. Pro logické odvození zákona o klesajícím relativním užitku mezním v rámci teleologického myšlení není tedy nezbytné předpokládat absolutní omezenost zdrojů v reálném světě, poněvadž jak se ukazuje u Loevensteinovy hospodářské fáze teleologického myšlení, je omezenost prostředků dána vždy relativně vzhledem k účelu. ${ }^{21}$

V rámci odlišení zastánců ekonomického apriorismu u B. Smitha22 je možné představitele Brněnské ekonomické školy zařadit mezi impozicionisty. Ti tvrdí, že

20 Přestože to není $u$ autorů Brněnské ekonomické školy explicitně uvedeno, nutnost volby je způsobena omezeností prostředků. Mises to vyjadřuje následovně: „Skutečnost, že člověk stojí na křižovatkách a že se musí rozhodovat a rozhoduje, vyplývá z kvantitativní podstaty světa. Člověk nežije ve světě bez kvantity, a ani si takový svět nedokáže představit." (Mises 2006, str.114)

21 Tato úvaha vyplývá z Englišovu konceptu relativní omezenosti prostředků. Naproti absolutní omezenosti dané objektivně jsou $\mathrm{v}$ rámci hospodářského myšlení prostředky omezeny relativně vzhledem k nejvyššímu účelu. Rovněž podle L. Robbinse je zákon klesajícího mezního užitku odvozen ze vzácnosti prostředků vzhledem k účelům, které naplňují. (Robbins 1942, str. 137)

${ }^{22} \mathrm{~B}$. Smith prosazuje myšlenku fenomenologicko-apriorní protovědy ke každé z empirických věd jako souboru všech non-empirických a non-analytických předpokladů daných empirických věd. Důsledně synteticky reinterpretovaná Misesova praxeologie by tak podle něho mohla sloužit za základ empiricky založené makroekonomie. (Pavlík 2004, str. 659) srov. (Smith 1999, str. 185-187) Syntetické soudy a priori nejsou u B. Smitha chápány impozicionisticky jako u Misese a Brněnské ekonomické školy, ale vyjadřují nutnost věcí samých, a nikoli nutnost myšlení. Požadavek na exaktní založení ekonomie se však neliší. 
apriorní struktury mají svůj původ v logické struktuře mysli, tedy na straně subjektu a Brněnská ekonomická škola se řadí velmi pravděpodobně mezi nejvýraznější stoupence. Reflekcionisté naopak tvrdí, že apriorní poznání je reflektováno př́mo ze struktury samotné skutečnosti, resp. že některé struktury této skutečnosti jsou pochopitelné samy ze sebe. Podle vlastních slov by měl být Mises považován také za stoupence impozicionismu, ovšem výsledky své praxeologie postuluje jako apodiktické ve vztahu k realitě jednání tak, jak se jeví v životě a historii.

Naopak u Loevensteina nevíme zcela apodikticky co se ve skutečnosti přihodí. ${ }^{23}$ Loevenstein tedy neaspiruje $\mathrm{k}$ apodiktickému popisu reálného světa, tak jako se o to snaží Mises. Hranice Loevensteinovy teleologie jsou od vzniku chtění něčeho jako prostředku ${ }^{24}$ až k rozhodnutí o jednání. Protože základem (racionalitou) teleologického způsobu myšlení je u Loevensteina logika, jsou teleologické (ekonomické) soudy pro intelekt apodikticky jisté. Přestože tedy rakouská škola nebyla jediná v souboji za metodologický apriorismus v ekonomii, zůstává Mises osamocen v přesvědčení, že aplikací logických zákonů (myšlení) na realitu nepozbývají tyto své apodiktičnosti. 25

Vrat'me se nyní k využití logiky v rámci ekonomie. Pokud by byla ekonomie nahlížena jako Teleologie Jana Loevensteina (resp. její hospodářská fáze), nebylo by pro ní zapotřebí ničeho jiného, než poznání logické struktury naší mysli, která tvoří řekněme most mezi naším intelektem a realitou. Tento most ( $v$ našem př́padě teleologický, resp. hospodářský způsob myšlení) je vždy přítomný, pokud pozorujeme předměty okolo sebe se zřetelem $\mathrm{k}$ nějakému účelu. Pokud je účel jediný a jednoznačný (vyhrát válku) jedná se o technickou fázi teleologického myšlení. V hospodářské fázi však izolovaný účel nefiguruje. Protože není svět pro člověka uchopitelný bez kvantity není jednoduché ani účelové plánování. Je zřejmé, že v př́ípadě plánování války (za jediným účelem) se postaví mnoho derivativních účelů do konfliktu (zjednodušeně: zda vyrobit více tanků nebo vrtulníků

\footnotetext{
23 „Netvrdím ovšem, že kausalita fysiologická (nebo psychologická) je tatáž jako přirozená, nebot' vedle ní je fyzický subjekt podroben i této přirozené kausalitě, na př. sklouzne-li kdo a padne“ (Loevenstein 1934, str.61)

${ }^{24}$ Loevensteinovu celkovou koncepci udává do pohybu předpoklad chtění a priori inspirovaný Schopenhauerem. Chtění něčeho (abstraktně) jako prostředku k účelu (jímž je v tomto př́padě chtění a priori) předchází chtění něčeho konkrétního jako prostředku. Toto chtění a priori je poté předpokladem $\mathrm{k}$ celé logické úvaze. Nebot' chtění něčeho jako prostředku předpokládá vždy chtění účelu, jenž subjekt pokládá za neuskutečnitelný bez prostředku.

${ }^{25}$ Rovněž Mises však svá tvrzení, že „věty získané správným praxeologickým uvažováním jsou nejen dokonale jisté a nevyvratitelné, stejně jako správné věty matematiky, ale navíc se s plnou přísností své apodiktické jistoty a nevyvratitelnosti vztahují k realitě jednání, jak se jeví v životě a historii.“ (Mises 2006, str.37) na základě toho, že rozum a jednání jsou dvěma stránkami téže mince, upravuje tím, že v kategorii jednání je nutně obsažena nejistota budoucnosti, způsobující to, že „Apodiktická jistota existuje pouze v rámci deduktivního systému apriorní teorie. Nejlepší, čeho lze s ohledem na realitu dosáhnout, je pravděpodobnost.“ (Mises 2006, str.96) Takové vyjádření ovšem již zcela koresponduje s impozicionismem Brněnské ekonomické školy.
} 
s omezenými možnostmi - materiálními, časovými atd.) a bude nezbytné mezi nimi volit s ohledem na účel základní, tedy vzhledem k relativní omezenosti prostředků $\mathrm{k}$ tomuto účelu.

Smyslem hospodářské fáze teleologického myšlení není nic odlišného, než volba popisovaná dodnes standardní ekonomii - tedy volba mezi statky v rámci omezení (např. rozpočtového). Teleologie na tyto otázky odpovídá, aniž by jí bylo zapotřebí nějakého empirického či psychologického předpokladu (s výjimkou existence subjektu), pouze $\mathrm{v}$ rámci logiky daného zprostředkování mezi subjektem a předmětem z hlediska účelu. Toto zprostředkování je pochopitelně nahlédnutelné pouze na nějakém předmětu ovšem tato struktura je u Brněnské školy vlastní subjektu (Kant). To je také důvod toho, proč je smysluplné požadovat něco jako metodologický apriorismus ve společenských vědách a zejména pak v ekonomii, a proč mohou teleologické poznatky nabývat zcela apodiktického charakteru pro intelekt do té doby, než se na reálný svět aplikují. Je pochopitelně možné tvrdit, že v pozici absolutní ideje (Hegel) bude tato struktura obsažena také v reálném světě (resp. naopak). ${ }^{26}$

\section{Závěr}

Závěrem této práce je formulace požadavku na poli ekonomické metodologie, který stojí za všemi výše uvedenými koncepty a je tak požadavkem společným. Tento požadavek velmi úzce souvisí s přesvědčením, že metody přírodních věd není vhodné nekriticky aplikovat na vědy společenské. Toto přesvědčení se však nezakládá na tom, že by taková aplikace nepřinášela žádné výsledky, ale je naopak vyjádřením obavy z toho, že právě vysoká četnost (mnohdy protichůdných) výsledků těchto empirických aplikací s sebou přináší zdání predikovatelnosti společenského jsoucna. ${ }^{27}$ Pracovní nástroj ekonomie zůstává stále chirurgicky přesný a zcela jistý. Jak přesný a jistý bude výsledek vždy záleží pouze na tom, za jakých podmínek se s tímto nástrojem pracuje.

Ekonom však musí s pokorou přiznat, že oblast toho, co může říci nade vši pochybnost, je s ohledem na všechny soudy obvykle užívané v ekonomické vědě jen

\footnotetext{
${ }^{26} \mathrm{~V}$ takovém světě bude každý reálný čin psychofyzického člověka veden objektivním duchem nutně $\mathrm{k}$ tomu, že jeho působení na reálné předměty bude vykazovat přesně takové výsledky, jaké daný subjekt předmětu přikládal při tom, když se rozhodoval o jednání. Na světě rovněž nezůstane jediný takový subjekt, u něhož by výsledky jeho aktivity (po tom, co se $\mathrm{k}$ tomu rozhodl) neodpovídaly jeho představám o těchto výsledcích před samotným rozhodnutím (jednoduše by se nepletl). $\mathrm{V}$ takovém světě by skutečně byla každá věc (událost) výsledkem volby (subjektu) resp. jejich interakcí. Pouze v takovém reálném světě by byla Misesova praxeologie aplikovatelná s plnou přísností své apodiktické jistoty. Již výše bylo v souvislosti s nejistotou budoucnosti prokázáno, že Mises si tento problém uvědomuje.

${ }^{27}$ „Rekonstrukcí racionálních základů intuitivního poznání ekonomů nás Mises přivedl na správnou cestu dalšího vývoje ekonomické vědy a ochránil nás před systematickým intelektuálním omylem.“ (Hoppe 1995, str.35)
} 
velmi malá. Ve vztahu $\mathrm{k}$ budoucímu stavu věcí je tato situace ještě komplikovanější. O to důležitější se zdá být ono nezbytné rozlišení. Základní společné požadavky na čistě logickou ekonomii jsou následující.

1) Fundamentální ekonomický zákon o klesajícím relativním čistém subjektivním výnosu mezním (zákon klesajícího mezního užitku) může být zdůvodněn logicky.

2) V takovém případě je smysluplné požadovat soubor (čistě logických) ekonomických soudů vydedukovaných pouze za použití prostředků formální logiky z tohoto fundamentálního zákona hospodářského jednání. ${ }^{28}$

3) Soubor takto získaných soudů oddělit od ostatních ekonomických poznatků, které jsou dedukovány z těchto exaktních zákonů přiřazením dalších empirických předpokladů.

4) Platnost poznatků získaných dedukcí ze souboru čistě logických ekonomických poznatků s přiřazením empirických předpokladů není dotčena, ovšem jejich význam pro skutečnost odpovídá výskytu přijatých empirických předpokladů. ${ }^{29}$

5) Pokud jde o platnost ostatních ekonomických poznatků, získaných jinými empirickými zpo̊soby, neměly by tyto být v rozporu s výše identifikovaným exaktním základem ekonomické vědy. Dodržení nastíněných metod zakládá správnost hospodářského myšlení.

6) Pokud jde o vzájemný vztah těchto oddělených souborů, platí, že platnost poznatků ze souboru čistě logických soudů nemůže být poznatky z dalších souborů verifikována či falzifikována, ani jiným způsobem ovlivněna. $\mathrm{Na}$ druhou stranu mohou být ekonomické poznatky tímto souborem čistě logických ekonomických soudů jak vyvráceny tak vytvořeny.

28 Takový soubor čistě logických poznatků může obsahovat nejen vztahy pojmů účelového myšlenkového řádu formulované Brněnskou př́ipadně Rakouskou školou (užitek, škoda, náklad, výnos, účel, prostředek, hodnota, hospodaření, spoření, směna atd.) nebo již zmíněný zákon o klesajícím relativním užitku mezním. Dále II. Gossenův zákon jako tendenční vyjádření maximalizační úlohy, jenž může vést $\mathrm{k}$ zahrnutí některých dalších formálních identit moderní mikroekonomie mezi tyto čistě logické ekonomické poznatky a umožnit kvantifikaci některých fenoménů. Logická platnost zákonů vydedukovaných autory rakouské tradice ze zákona klesajícího mezním užitku je rovněž součástí tohoto souboru (např. zákon o klesajících výnosech z výrobních faktorů či zákon o komparativní výhodě)

${ }^{29}$ Do tohoto souboru mohou náležet praxeologické teorie rakouské tradice stejně jako ekonomické poznatky teorie her a některé "mikroekonomicky založené poznatky "makroekonomie hlavního proudu“. Tím se však zásadní otázkou stávají předpoklady. Zatímco autoři rakouské tradice přistupují kumulováním jednoduchých předpokladů (teorie nepř́mé směny, hospodářský cyklus atd.), při konstrukci předpokladů u teorie her je pro praktický význam nutné zdůvodnit, proč pouze použité předpoklady jsou vyčerpávající charakteristikou popisované skutečnosti. Obdobně jako tomu je u všech komplikovanějších ekonomických modelů. 


\section{Bibliography}

BECKER, Arthur Peter: Some philosophical Aspects of Economics, Philosophy of Science, Vol.15, No. 3 (Jul.,1948) str. 242 - 246

ENGLIŠ, Karel: Malá logika, 1. vydání, Praha, Melantrich, 1947, str. 511

ENGLIŠ, Karel: Teleologie jako forma vědeckého poznání, Praha, Topič 1930

ENGLIŠ, Karel: Věčné ideály lidstva, Praha, Vyšehrad 1992, str. 160

HAYEK, Friedrich August von: Kontrarevoluce vědy, Praha, Liberální institut, 1995, str. 212, ISBN 80-85787-87-3

HOPPE, Hans-Hermann: Economic Science and the Austrian Method, The Ludwig von Mises Institute, 1995, In: Demokracie, anarchie a omyly ekonomie, 1. vydání, Praha, Liberální institut 2009, str. 184

LOEVENSTEIN, Jan: Formální vědní odvětví teleologického myšlení, Praha, Tiskárna Aloise Wiesnera, 1932

LOEVENSTEIN, Jan: O jednotnou konstrukci finanční vědy (poznámky ku Englišově kritice), Brno, Barvič\&Novotný, 1929

LOEVENSTEIN, Jan: Velká Teleologie, 1933

MISES, Ludwig von: Lidské jednání, Praha, Liberální institut, 2006, str. 959, ISBN 80 86389-45-6

PAVLÍK, Ján: F.A.Hayek a teorie spontánnîho řádu, 1. vydání, Praha, Professional Publishing, 2004, str. 805, ISBN 80-86419-57-6

ROBBINS, Lionel: An Essay on The Nature and Significance of economic Science, 2. vydání, London, Macmillan, 1945

ROTHBARD, Murray N.: Zásady Ekonomie: Od lidského jednání k harmonii trhů, Praha, Liberální institut, 2005, str. 755, ISBN 80-86389-27-8

SMITH, Barry: Apriorismus v ekonomii, Liberální institut, 2008, př́istup z internetu: http://www.libinst.cz/etexts/smith_apriori.pdf

SMITH, Barry: In Defence of Extréme (Fallibilistic) Apriorism: Journal of Libertarian Studies, číslo 1/12, 1999 
SCHOPENHAUER, Arthur: $O$ čtverém kořeni věty o dostatečném důvodu, in: Vůle $\mathrm{v}$ prrírodě a jiné práce, Praha, Academia, 2007, str. 599 


\section{E-LOGOS}

\section{ELECTRONIC JOURNAL FOR PHILOSOPHY}

Ročník/Year: 2010 (vychází průběžně/ published continuously)

Místo vydání/Place of edition: Praha

ISSN 1211-0442

Vydává/Publisher:

Vysoká škola ekonomická v Praze / University of Economics, Prague

nám. W. Churchilla 4

Czech Republic

13067 Praha 3

IČ: 61384399

Web: http://e-logos.vse.cz

Redakce a technické informace/Editorial staff and technical information:

Miroslav Vacura

vacuram@vse.cz

Redakční rada/Board of editors:

Ladislav Benyovszky (FHS UK Praha)

Ivan Blecha (FF UP Olomouc)

Martin Hemelík (Masarykovo klasické gymnázium, Říčany u Prahy)

Angelo Marocco (Pontifical Athenaeum Regina Apostolorum, Rome)

Jozef Kelemen (FPF SU Opava)

Daniel Kroupa (ZU Plzeň)

Vladimír Kvasnička (FIIT STU Bratislava)

Jaroslav Novotný (FHS UK Praha)

Jakub Novotný (Vysoká škola polytechnická, Jihlava)

Ján Pavlík (editor-in-chief) (VŠE Praha)

Karel Pstružina (VŠE Praha) 